SANITARNO INŽENIRSTVO / International Journal of Sanitary Engineering Research 2020;14(1):4-16

DOI: 10.2478/ijser-2020-0002

\section{An evaluation of the effectiveness of nudge techniques in improving hygiene behaviours in Kindergartens}

\author{
Natalija ROZMAN ${ }^{1 *}$, Branka STRAH ${ }^{2}$, Mojca JEVŠNIK ${ }^{1}$
}

\begin{abstract}
Good hygiene practice is an important element in terms of preventing the spread of infections, but it is not always carried out according to instructions among employees in hygienically sensitive work processes. To improve this, tools for nudging hygienic behaviour have been developed, which subconsciously encourage the individual to perform the desired hygienic behaviour. Examples of activity where employees and children constantly come into contact with pathogenic microorganisms are educational institutions (kindergartens). By observing the working process in the selected kindergartens, we wanted to determine the time, technique, and frequency of handwashing among childcare workers and children. In the case of the first ones, we wanted to find out whether they also wear personal protective work equipment. Based on the findings, we wanted to implement the selected nudging tools for better hygiene behaviour. In the first half of the observation, we found that the hygienic behaviour regarding handwashing of childcare workers and children is poor. After setting the nudging tools, hygienic behaviour improved in all the observed groups. The results suggest that the use of nudging tools in kindergartens can significantly contribute to the better implementation of hygienic behaviour (especially handwashing) in childcare workers and children. Consequently, we conclude that with the tools for promoting hygiene behaviour, the incidence of infectious diseases in kindergartens can be reduced. We can direct children towards the healthier and hygienically appropriate way of life by means of the appropriate hygiene behaviour.
\end{abstract}

Key words: preschool education; handwashing; hand hygiene; behaviour; nudging tools

\section{POVZETEK}

Dobra higienska praksa je pomemben element $v$ smislu preprečevanja širjenja okužb, vendar se med zaposlenimi v higiensko občutljivih delovnih procesih ne izvaja vedno po navodilih. Za izboljšanje le-tega so se oblikovala orodja spodbujanja higienskega vedenja, ki podzavestno spodbudijo posameznika $\mathrm{k}$

\section{sciendo}

Original scientific article

Received: 3. 09. 2020

Accepted: 2. 12. 2020

Published: 31. 12. 2020

${ }^{1}$ Faculty of Health Sciences, University of Ljubljana, Zdravstvena pot 5, 1000 Ljubljana, Slovenia

${ }^{2}$ Kindergarten Kekec Grosuplje, Trubarjeva cesta 15, 1290 Grosuplje, Slovenia

* Corresponding author Natalija Rozman, MSc Sanitary Engineering

Currently at National Institute of Public Health, Trubarjeva 2,

1000 Ljubljana, Slovenia

E-mail: natalija.rozman1@gmail.com

(C) 2020 Natalija Rozman, Branka Strah, Mojca Jevšnik. This is an open access article licenced under the Creative Commons Attribution NonCommercialNoDerivs license as currently displayed on http://creativecommons.org/licenses/ by-nc-nd/4.0/. 
izvajanju želenega higienskega vedenja. Primer dejavnosti, pri kateri zaposleni in otroci pogosto prihajajo $v$ stik $s$ patogenimi mikroorganizmi, so vzgojno varstveni zavodi (vrtci). Z opazovanjem delovnega procesa $v$ izbranih vrtcih smo želeli ugotoviti čas, tehniko in pogostost umivanja rok pri strokovnih delavkah in pri otrocih. Pri prvih tudi ali uporabljajo osebna zaščitna sredstva. Na osnovi ugotovitev smo želeli uvesti izbrana orodja spodbujanja higienskega vedenja in ugotoviti, ali ta izboljšajo higiensko vedenje opazovancev. $\mathrm{V}$ prvi polovici opazovanja smo ugotovili, da je higiensko vedenje glede umivanja rok strokovnih delavk in otrok na nizki ravni. Po namestitvi spodbujevalnih orodij se je higiensko vedenje izboljšalo pri vseh opazovancih. Rezultati nakazujejo, da lahko uporaba spodbujevalnih orodij na področju umivanja rok v vrtcih bistveno pripomore $\mathrm{k}$ boljšemu izvajanju higienskega vedenja (predvsem umivanje rok) strokovnih delavk $v$ oddelkih in otrok. Posledično sklepamo, da lahko z orodji spodbujanja higienskega vedenja zmanjšamo pojavnost nalezljivih bolezni $v$ vrtcih ter hkrati otroke $\mathrm{z}$ ustreznim higienskim vedenjem usmerjamo $\mathrm{k}$ bolj zdravemu in higiensko ustreznemu načinu življenja.

Ključne besede: predšolska vzgoja; umivanje rok; higiena rok; vedenje; spodbujevalna orodja

\section{INTRODUCTION}

Nowadays, there are many theoretical and practical training courses on good hygiene practice (referred as GHP) such as proper hand hygiene. According to the scientific literature, such implementation is a constant challenge $[1,2,3,4]$ due to poor knowledge, superficiality, overload and/or employee disinterest and skin irritation. The fact is that an individual's behaviour in the field of hygiene practices affects the health of everyone, that he or she comes into contact with. For more consistent implementation of hygiene practices, nudging tools have been developed to encourage the individual to perform the desired action (e.g. handwashing) [3]. Nudging tools in the field of hand hygiene are important, as many studies shows an association between improved hand hygiene and a reduction in the number of diseases [2, 5, 6]. An example of an activity in which employees and children often come into contact with infections are educational institutions (kindergartens). There, regular and proper exercise of handwashing is crucial, as otherwise the health of employees, children and parents is at stake. Simple, cost-effective tools for promoting hygienic behaviour can help target behaviours to be improved and motivated by childcare workers and children $[3,7]$.

The term "nudge" was first described by the authors Thaler and Sunstein (8) as a "gentle push" with the main goal of directing people's behaviour towards a better decision. This definition has been labelled in scientific circles as too broad and imprecise. Therefore, they stipulated that incentives must meet certain requirements. Nudges must be lowcost, simple, easy to reject (without coercion) and nudges need to help people make better decisions (safer and healthier).

The health hygiene regime in kindergarten is based on ensuring a safe and healthy environment. An important factor is regular and proper
Nudges must be low-cost, simple, easy to reject (without coercion) and nudges need to help people make better decisions (safer and healthier). 
The main purpose of handwashing is to prevent the transmission of microorganisms that are applied to the skin of the

hands in contact with surfaces and other persons, objects and the environment.

This prevents the contact spread of infectious diseases.

During the handwashing process itself, in addition to the time and technique of washing, the encouragement (supervision) of children is also crucial. handwashing. The main purpose of handwashing is to prevent the transmission of microorganisms that are applied to the skin of the hands in contact with surfaces and other persons, objects and the environment. This prevents the contact spread of infectious diseases. Handwashing of children and childcare workers in kindergarten is essential: before entering the playroom, before preparing meals, before and after meals, after outdoor activities, after using the toilet, after nose cleaning, coughing, sneezing and after changing diapers. During the handwashing process itself, in addition to the time and technique of washing, the encouragement (supervision) of children is also crucial $[9,10]$.

The aim of the research was to determine: a) time, technique and frequency of handwashing among childcare workers and children, b) in the case of the first ones, we wanted to find out whether they comply with hygiene tidiness criteria and wear personal protective work equipment and c) based on the findings, we wanted to implement the selected nudging tools for better hygiene behaviour and measure its improvement.

\section{METHODS}

\section{Type of research methodology, techniques and methods of data collection}

In the research a qualitative methodology and descriptive method of work were used. The method of data collection is open observation of childcare workers and children in the practice of handwashing (time, technique and frequency), in the case of the first ones, also the hygienic tidiness and whether they wear personal protective work equipment.

For observation, we created and used an observation list with criteria for proper handwashing (time, technique, frequency) of all observers and with criteria for hygienic tidiness and use of personal protective work equipment of childcare workers.

\section{Research strategy, sample and data analysis}

We used a case study. The units of study are two kindergartens. We selected purposeful and non-random samples consisting of two wards of children with first age range (2-3 years), two wards of children with second age range (4-6 years) and childcare workers from each ward. The whole observation took place for eight weeks and simultaneously in both kindergartens with the prior given oral consent by the kindergarten principals. Then we asked childcare workers to give their written consent. When they agreed to participate, we also informed children's parents about the research process in written statement. The kindergarten health and hygiene regimen staff then confirmed to us through e-mail the participation of all childcare workers and children in the survey.

In the first kindergarten, we firstly observed the ward of the first age range for two weeks. After that, we have selected several nudging tools to promote hygienic behaviour, set and tested them in a childcare work 
environment. The observing time ( 2 weeks) after the installation of nudging tools was the same as the observing time before the installation of those tools. The ward of the second age range was then observed in the same kindergarten for two weeks, followed by the installation of the same tools as in the first age ward, and then observed for another two weeks. The same procedure was then repeated in the second kindergarten, where the selected groups were observed half the time less than those in the first kindergarten. All observation data were marked in the observation list.

The selected nudging tools were:

- a poster made in A4 size, showing (hygiene requirements) when the handwashing is necessary;

- plasticized rectangular pictures, measuring approximately $8 \times 6,5$ $\mathrm{cm}$. The first picture showed handwashing with running water and soap. Second picture showed a cheerful smile, which was used as a hint for a well done job (thumbs up). Both images were placed next to the soap dispensers in the selected observed groups/wards;

- the story of a tractor that illustrates proper handwashing technique, which was introduced in the morning round (an educational work process in which children and childcare workers sit on cushions and learn new concepts) [11];

- poster created on AO format. Handwashing technique, shown step by step with pictures of hand movements, mowing and hay harvesting with tractor. The poster was hung in the washrooms above the sinks;

- practical learning of handwashing at the sink for each child individually.

In the end, an analysis of all the obtained data was made and a comparison with the observation results before and after the introduction of the nudging tools. The analysis of the data was prepared in summary form so that the individual cannot be recognized and thus the anonymity of all participants was guaranteed. The data were analysed using an Excel computer program. The Equation 1 was used to calculate consistency of proper handwashing of childcare workers.

Equation 1. Basic consistency calculation of handwashing [12]:

$$
\begin{gathered}
\text { Consistency of } \\
\text { proper behavior }(\%)
\end{gathered}=\frac{\text { number of actions }}{\text { number of opportunities }} \times 100
$$

For analysing children's results, we used the scaling method to compare the results before and after the use of nudging tools (Equation 2).

Equation 2. Scaling calculation:

Scaling method
$\begin{aligned} & \text { (scaled No. of children } \\ & \text { who perform specified } \\ & \text { criterion appropriately) }\end{aligned}=\frac{\begin{array}{l}\text { No. of children who perform the } \\ \text { specified criterion appropriately }\end{array}}{\times}$
smaller No. of all children present


Figure 1.

Two of selected, set and tested nudging tools

Note:

Two of selected, set and tested nudging tools are hint pictures, placed next to the soap dispensers and poster of handwashing technique, hung above the

In this way, we adjusted the results of the number of all present children for all observed parameters so that the groups of children before and after the nudging tools were identical. The scaling results were then inserted into the consistency equation for performing handwashing by children (Equation 3).

Equation 3. Consistency calculation of children's handwashing using scaling:

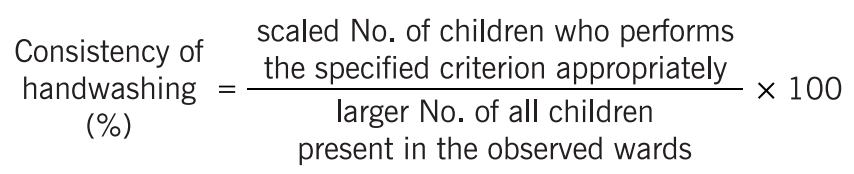

\section{RESULTS}

In the practical part of the research, we made a total of 60 observations of hygiene behaviour through the elaborated observation list. Of these, 30 observations were made before the introduction of nudging tools and 30 observations after the introduction of nudging tools. Table 1 and 2 show the observation results of the hygiene tidiness and handwashing of children and childcare workers. The results in table 1 and 2 are shown by the number of observations of proper hygiene behaviour and by percentages (\%). A 100\% share means that the observed parameter out of a total of 30 observations or opportunities has been correctly (appropriately) performed each time. The most common causes (disruptive factors) of inadequate hygiene behaviour are also listed. Figure 1 shows two of the selected nudging tools, that were used during practical part of the research.




Table 1. Observation results of hygienic tidiness of childcare workers before and after the use of nudging tools and causes for their inadequate hygiene behaviour

\begin{tabular}{|l|c|c|c|c|l|}
\hline \multirow{2}{*}{$\begin{array}{c}\text { Observation } \\
\text { criteria }\end{array}$} & \multicolumn{2}{|c|}{ Before using NT } & \multicolumn{2}{c|}{ After using NT } & \multicolumn{2}{|c|}{$\begin{array}{c}\text { Causes of inadequate } \\
\text { hygiene behaviour }\end{array}$} \\
\cline { 2 - 5 } & A (n) & A (\%) & B (n) & B (\%) & 70 \\
\hline $\begin{array}{l}\text { 1. Unvarnished and trimmed } \\
\text { nails }\end{array}$ & 19 & 63 & 21 & $\begin{array}{l}\text { Not complying the prescribed health } \\
\text { and hygiene regimen (subjective cause). }\end{array}$ \\
\hline 2. Absence of wearing jewellery & 20 & 67 & 19 & 63 & $\begin{array}{l}\text { Not complying the prescribed health } \\
\text { and hygiene regimen (subjective cause). }\end{array}$ \\
\hline 3. Appropriate health condition & 30 & 100 & 30 & 100 & $/$ \\
\hline
\end{tabular}

Note: NT - nudging tools; A (n) - the number of observations of proper hygiene tidiness before the introduction of NT; A (\%) - the number of observations of proper hygiene tidiness before the introduction of NT, shown as a percentage (\%); B (n) - the number of observations of proper hygiene tidiness after the introduction of NT; B $(\%)$ - the number of observations of proper hygiene tidiness after the introduction of NT, shown as a percentage (\%).

Table 2. Observation results of handwashing of childcare workers and children under certain hygiene requirements and causes for their inadequate handwashing

\begin{tabular}{|c|c|c|c|c|c|c|c|c|c|c|c|c|c|c|}
\hline \multirow{3}{*}{\multicolumn{2}{|c|}{$\begin{array}{l}\text { Observation } \\
\text { criteria }\end{array}$}} & \multicolumn{6}{|c|}{ Before using NT } & \multicolumn{6}{|c|}{ After using NT } & \multirow{3}{*}{$\begin{array}{l}\text { Causes of inadequate } \\
\text { hygiene behaviour }\end{array}$} \\
\hline & & \multicolumn{3}{|c|}{$A(n)$} & \multicolumn{3}{|c|}{$A(\%)$} & \multicolumn{3}{|c|}{$B(n)$} & \multicolumn{3}{|c|}{ B (\%) } & \\
\hline & & $\mathbf{T}$ & $\mathrm{Tq}$ & $\mathbf{S}$ & $T$ & $\mathrm{Tq}$ & $\mathbf{S}$ & $\mathrm{T}$ & $\mathrm{Tq}$ & $\mathrm{S}$ & $\mathbf{T}$ & $\mathrm{Tq}$ & $\mathrm{S}$ & \\
\hline \multirow{2}{*}{$\begin{array}{l}\text { 1. Washing children's } \\
\text { hands after } \\
\text { entering the } \\
\text { playroom }\end{array}$} & parents & 0 & 0 & 0 & 0 & 0 & 0 & 0 & 0 & 0 & 0 & 0 & 0 & There were no sinks available. \\
\hline & $\begin{array}{l}\text { childcare } \\
\text { workers }\end{array}$ & 2 & 0 & 2 & 7 & 0 & 7 & 0 & 0 & 0 & 0 & 0 & 0 & $\begin{array}{l}\text { Superficiality, rushing, unattended } \\
\text { children. }\end{array}$ \\
\hline $\begin{array}{l}\text { 2. Handwashing } \\
\text { before meal } \\
\text { preparation }\end{array}$ & $\begin{array}{l}\text { childcare } \\
\text { workers }\end{array}$ & 6 & 3 & 19 & 20 & 11 & 68 & 5 & 9 & 19 & 18 & 31 & 68 & Rushing, superficiality. \\
\hline \multirow[t]{2}{*}{$\begin{array}{l}\text { 3. Handwashing } \\
\text { before meal }\end{array}$} & $\begin{array}{l}\text { childcare } \\
\text { workers }\end{array}$ & 1 & 2 & 19 & 2 & 7 & 64 & 8 & 9 & 20 & 27 & 30 & 66 & Rushing, superficiality. \\
\hline & children & 3 & 3 & 11 & 10 & 10 & 37 & 21 & 21 & 27 & 70 & 70 & 90 & $\begin{array}{l}\text { Rushing (on the command of } \\
\text { childcare workers) and superficiality. }\end{array}$ \\
\hline \multirow[t]{2}{*}{$\begin{array}{l}\text { 4. Handwashing after } \\
\text { meal }\end{array}$} & $\begin{array}{l}\text { childcare } \\
\text { workers }\end{array}$ & 1 & 1 & 7 & 2 & 2 & 23 & 6 & 8 & 14 & 20 & 27 & 47 & \multirow{2}{*}{ Rushing, superficiality. } \\
\hline & children & 4 & 3 & 11 & 13 & 10 & 37 & 21 & 21 & 27 & 70 & 70 & 90 & \\
\hline \multirow[t]{2}{*}{$\begin{array}{l}\text { 5. Handwashing after } \\
\text { completed activities }\end{array}$} & $\begin{array}{l}\text { childcare } \\
\text { workers }\end{array}$ & 3 & 3 & 12 & 10 & 10 & 40 & 11 & 11 & 18 & 37 & 37 & 60 & $\begin{array}{l}\text { Rushing, superficiality and belief } \\
\text { that they have enough clean hands. }\end{array}$ \\
\hline & children & 6 & 4 & 15 & 20 & 13 & 50 & 23 & 21 & 26 & 77 & 70 & 87 & Rushing, superficiality. \\
\hline $\begin{array}{l}\text { 6. Supervision and } \\
\text { assistance in } \\
\text { washing children's } \\
\text { hands } \\
\end{array}$ & $\begin{array}{l}\text { childcare } \\
\text { workers }\end{array}$ & 6 & 6 & 11 & 20 & 20 & 37 & 7 & 13 & 16 & 23 & 43 & 53 & $\begin{array}{l}\text { Lack of encouragement and only } \\
\text { verbal referral to children for wash } \\
\text { their hands. }\end{array}$ \\
\hline \multirow[t]{2}{*}{$\begin{array}{l}\text { 7. Handwashing after } \\
\text { changing diapers }\end{array}$} & \begin{tabular}{|l} 
childcare \\
workers
\end{tabular} & 4 & 2 & 10 & 24 & 13 & 67 & 4 & 6 & 10 & 24 & 40 & 67 & Rushing, superficiality. \\
\hline & children & 16 & 4 & 16 & 53 & 13 & 53 & 19 & 15 & 20 & 63 & 50 & 67 & $\begin{array}{l}\text { Rushing (on the command of } \\
\text { childcare workers) and superficiality. }\end{array}$ \\
\hline \multirow[t]{2}{*}{$\begin{array}{l}\text { 8. Handwashing after } \\
\text { cleansing nose }\end{array}$} & $\begin{array}{l}\text { childcare } \\
\text { workers }\end{array}$ & 2 & 0 & 1 & 15 & 0 & 8 & 0 & 0 & 2 & 0 & 0 & 15 & Superficiality. \\
\hline & children & 3 & 1 & 6 & 10 & 3 & 20 & 3 & 1 & 3 & 10 & 3 & 10 & $\begin{array}{l}\text { Lack of encouragement, rushing and } \\
\text { superficiality. }\end{array}$ \\
\hline $\begin{array}{l}\text { 9. Handwashing after } \\
\text { using the toilet }\end{array}$ & children & 3 & 3 & 11 & 10 & 10 & 37 & 21 & 21 & 27 & 70 & 70 & 90 & $\begin{array}{l}\text { Rushing (on the command of } \\
\text { childcare workers) and superficiality. }\end{array}$ \\
\hline
\end{tabular}

Note: NT - nudging tools, T - time of handwashing, Tq- handwashing technique, $\mathrm{S}$ - use of soap; A ( $\mathrm{n}$ ) - the number of observations of proper handwashing before the introduction of NT; $\mathrm{A}(\%)$ - the number of observations of proper handwashing before the introduction of NT, shown as a percentage (\%); B (n) - the number of observations of proper handwashing after the introduction of NT; B (\%) - the number of observations of proper handwashing after the introduction of NT, shown as a percentage (\%). 
Table 3. Observation results of the use of personal protective work equipment of childcare workers before and after the use of nudging tools and causes of their inadequate hygiene behaviour.

\begin{tabular}{|l|c|c|c|c|l|l|}
\hline \multirow{2}{*}{$\begin{array}{c}\text { Observation } \\
\text { criteria }\end{array}$} & \multicolumn{2}{|c|}{$\begin{array}{c}\text { Before using } \\
\text { NT }\end{array}$} & \multicolumn{2}{|c|}{$\begin{array}{c}\text { After using } \\
\text { NT }\end{array}$} & \multicolumn{2}{|c|}{$\begin{array}{c}\text { Causes of inadequate } \\
\text { hygiene behaviour }\end{array}$} \\
\cline { 2 - 6 } & A (n) & A (\%) & B (n) & B (\%) & \\
\hline 1. Wearing work clothes and shoes & 25 & 83 & 25 & 83 & $\begin{array}{l}\text { Same footwear for indoor and outdoor } \\
\text { playroom areas } \rightarrow \text { superficiality. }\end{array}$ \\
\hline $\begin{array}{l}\text { 2. Wearing hygienic apron to distribute } \\
\text { food }\end{array}$ & 9 & 30 & 10 & 33 & $\begin{array}{l}\text { Childcare workers at one kindergarten did not } \\
\text { have an apron available (not provided). }\end{array}$ \\
\hline $\begin{array}{l}\text { 3. For the first age range only: Use of } \\
\text { protective gloves (diaper changing of } \\
\text { children in the event of illness and potty } \\
\text { cleaning) }\end{array}$ & 10 & 67 & 15 & 100 & Rushing, superficiality. \\
\hline
\end{tabular}

Note: NT - nudging tools; A (n) - the number of observations of proper hygiene behaviour before the introduction of NT; A (\%) - the number of observations of proper hygiene behaviour before the introduction of NT, shown as a percentage (\%); B (n) - the number of observations of proper hygiene behaviour after the introduction of NT; B (\%) - the number of observations of proper hygiene behaviour after the introduction of NT, shown as a percentage (\%).

\section{Childcare workers do not}

follow the kindergarten's

health hygiene regime, which stipulates that nails must be trimmed and unvarnished and jewellery must be removed before starting childcare work.

Obtained results also shows that childcare workers do not perform handwashing for a sufficient amount of time, with proper technique, and not often enough with every hygiene requirement.
Table 3 shows whether childcare workers used personal protective work equipment appropriately. The results in table 3 are shown by the number of observations of proper hygiene behaviour and by percentages (\%). A $100 \%$ share means that the observed parameter out of a total of 30 observations or opportunities has been correctly (appropriately) performed each time. The most common causes (disruptive factors) of inadequate hygiene behaviour are also listed.

\section{DISCUSSION}

\section{Hygienic tidiness and handwashing of childcare workers before the use of nudging tools and causes for their inadequate hygiene behaviour}

Hygienic tidiness of childcare workers is important for the protection of children's health and to avoid potential health hazards (e.g. long nails and jewellery can injure children and at the same time allow the retention of microorganisms and their spread to children and objects) [12]. Prior to any use of nudging tools, childcare workers performed best in their health condition that was adequate throughout the observation (did not pose a health risk). Obervers performed worse in the first two observation criterias (Unvarnished and trimmed nails; Absence of wearing jewellery). The causes of inadequate hygiene behaviour of these two criterias are difficult to determine and are mostly of subjective origin (superficiality, rushing and thinking that long and varnished nails and wearing jewellery do not pose a health risk). The fact is that in this regard, childcare workers do not follow the kindergarten's health hygiene regime, which stipulates that nails must be trimmed and unvarnished and jewellery must be removed before starting childcare work [9].

Obtained results also shows that childcare workers do not perform handwashing for a sufficient amount of time, with proper technique, and not often enough with every hygiene requirement. The lowest results 
were technique and time of handwashing (less than 20 seconds). The most common causes for inadequate behaviour are rush, superficiality and the assumption that the hands are already clean enough. They also performed poorly in supervision and assistance in washing children's hands. In most cases, encouragement was present only as a verbal referral to children for washing their hands, but not in detail in terms of their control over appropriate timing and washing techniques and the use of soap. As there is no other research available on observing handwashing of childcare workers, we can compare our findings with those in the field of health. Lack of hand hygiene (handwashing and hand disinfection) has been identified in a number of studies in healthcare professionals [4, 13, 14]. They, like the observers in our study, performed handwashing/hand disinfection with lacking frequency (they did not comply with hygiene requirements). Due to their rush and superficiality, they also performed in some cases inappropriate time and technical execution of handwashing / disinfection. Studies around the world, therefore, suggests that handwashing is insufficiently controlled in hygienically sensitive institutions (even in developed countries). At the same time, too few measures have been put in place to properly and regularly implement it.

\section{Use of personal protective work equipment of childcare workers before the use of nudging tools and causes of their inadequate hygiene behaviour}

We also wanted to find out if childcare workers use personal protective work equipment in the work process. They performed best when wearing work clothes and shoes. However, the most common causes of poor hygiene behaviour were wearing the same footwear in the indoor and outdoor playroom areas (e.g. when children were playing on the patio, childcare workers wore the same footwear as in the indoor playroom). With that, they enable the pollution of the indoor playroom and also possible transfer of microorganisms from the outside to the inside of the playroom. The use of protective gloves was observed only in first age range (ward), as there were no longer daily diapers changing in the older age ranges (wards) (except in the case of illnesses, which were not discovered in the time of observation). In comparison with the childcare assistants, the childcare teachers performed better. The reason for the incorrect use of protective gloves was because of the rushing to the following tasks. Observers performed worst when wearing an apron to distribute food. When distributing food, we come in contact with it and wearing an apron is absolutely essential. Also, in one of the two selected kindergartens observers used an apron for distributing food while in the other it was not possible (the kindergarten did not provide it). Poor and/or lack of knowledge of the importance of personal hygiene and the use of personal protective work equipment of workers in the food industry has identified many similar studies worldwide. They all came to the conclusion that in order to protect the health of consumers and employees and to prevent cross-contamination, the knowledge of workers who comes in food contact, needs to be constantly upgraded, repeated and verified [15, 16, 17]. Knowledge
The most common causes for inadequate behaviour are rush, superficiality and the assumption that the hands are already clean enough.

The most common causes of poor hygiene behaviour were wearing the same footwear in the indoor and outdoor playroom areas.

With that, they enable the pollution of the indoor playroom and also possible transfer of microorganisms from the outside to the inside of the playroom.

The reason for the incorrect use of protective gloves was because of the rushing to the following tasks. 
A higher age of children (greater ability to think) does not yet mean a better handwashing practice.

All of the nudging tools were installed in a visibly place at all times, allowing children and childcare workers to constantly repeat and learn how to properly wash their hands. and awareness of the importance of good hygiene practice in food management is essential to reduce food-related outbreaks/poisonings [18].

\section{Handwashing of children under certain hygiene requirements before the use of nudging tools and causes for their inadequate hygiene behaviour}

Regarding children's handwashing, all children together and also as individual age classes (wards), performed best when using soap during handwashing, while time and technique of handwashing were poorer. Nevertheless, the share of soap use was still low or below $50 \%$. One of the most common causes for inadequate washing of children 's hands is the rush on command of childcare workers. During the observation, we found out that children do not know that after sneezing, coughing and/ or cleansing their nose, they should always wash their hands. Dreibelbis et al. [6] found out that children with the absence of the nudging tools do not perform proper hygiene behaviour (especially handwashing). They were aware that children with new hygiene habits would be able to live healthier also in adult life. From the obtained results, we can also conclude that a higher age of children (greater ability to think) does not yet mean a better handwashing practice. Results indicate that children of the first age ward performed better handwashing practice. A similar finding was made by Au et al. [2], who concluded that for children (4-6 age), improved theoretical knowledge of proper handwashing does not necessarily mean improved practical handwashing knowledge.

Given the obtained results before any use of nudging tools, we found out that both theoretical and practical knowledge of handwashing at selected kindergartens were low. Therefore, we have chosen simple and affordable tools to promote hygienic behaviour. We sat in a morning circle (round) in the playroom with children and childcare workers. Then we began with a detailed explanation and meaning of the poster, pictorially showing when to wash hands (after coughing, after using the toilet, after playing, before cooking, etc.) and placed it in a visibly place in the playroom and at the height of children. For the proper handwashing, we introduced the story of mowing and hay harvesting with tractor to all observers. Through it, we learned together the time (at least 20 seconds) and technical implementation of handwashing, including the use of soap. In order to better remember the story, we transferred it pictorially to a poster (AO) and hung it in the washrooms above the sinks.

Next to the soap dispensers, we installed a picture of handwashing with running water and soap, and a picture of a cheerful smile that indicated a well done job (thumbs up). In order to provide the best possible visualization and regular handwashing, to each child individually the procedure of proper handwashing at the sink (use of running warm water, soap and towels) was shown. All of the nudging tools were installed in a visibly place at all times, allowing children and childcare workers to constantly repeat and learn how to properly wash their hands. After that, we began to re-watch all the observers. In addition, during the observation 
period in each morning circle, we reiterated the importance of the made posters and stories.

\section{Hygienic tidiness and the use of personal protective work equipment of childcare workers after the use of nudging tools}

After the use of nudging tools, the hygienic tidiness of childcare workers in varnished and trimmed nails improved by $6 \%$, while wearing jewellery increased by $3 \%$. The health condition remained the same $(100 \%)$ as before the introduction of the nudging tools. Because we did not use direct nudging tools to remind observers of their hygienic tidiness, the obtained results are not surprising. Nevertheless, after the use of nudging tools, the situation could be better, since in the morning round with children and childcare workers we told them what the proper hygienic tidiness means. Very similar goes for wearing work clothes and footwear, and an apron (criteria for personal protective work equipment). The opposite result was observed in the use of protective gloves, with $36 \%$ use improved. The reason for this is probably our mention of the importance of protecting the health of employees and children, which is also reflected in the use of protective gloves when changing diapers.

\section{Handwashing of childcare workers and children under certain hygiene requirements after the use of nudging tools}

The highest improvement was observed in handwashing of all observers, where direct nudging tools were used. Namely, all observers experienced nudging tools positive. Handwashing of childcare workers improved about $20-30 \%$, where they performed best in the technical and timely implementation of handwashing. Even more improvement was seen in children who washed their hands about 50-60\% more appropriately. Nudging tools that were used in the research, have advantage in its simplicity and affordability. The same conclusion reached also other studies, which used nudging tools for improving children's handwashing in kindergarten and school [2, 6, 19].

To improve handwashing, we advise childcare workers to practice the appropriate time (at least 20 seconds) and technique (to cover all areas of the hands) of handwashing and to use a sufficient amount of soap (1 push or $1 \mathrm{ml}$ of liquid soap per person for a single wash) [20]. In doing so, it is crucial to avoid rushing and superficiality and to not encourage children to do so. In addition, it is important to finish a certain educational process (e.g. playing in a playroom, outdoor activities, etc.) a few minutes earlier to instruct children to wash their hands in a timely manner. They will therefore have sufficient time to perform handwashing. Also, children should be regularly encouraged, taught and assisted in the process of handwashing (through various stories, songs, games, folders and posters). All of these are affordable and easy to use nudging tools for which there should be no excuse for not using them. Despite important findings, the survey has some limitations related to the relatively small sample of observers in relation to the total number of kindergartens in Slovenia, the questionable longevity of nudging tools and the potential bias of the
After the use of nudging tools, the hygienic tidiness of childcare workers in varnished and trimmed nails improved by $6 \%$, while wearing jewellery increased by $3 \%$.

Handwashing of childcare workers improved about 20-30\%, where they performed best in the technical and timely implementation of handwashing.

It is important to finish a certain educational process (e.g. playing in a playroom, outdoor activities, etc.) a few minutes earlier to instruct children to wash their hands in a timely manner. 
The use of nudging tools in kindergartens can significantly

contribute to a better

implementation of hygienic behaviour of childcare workers and children.

\section{The importance of hygiene behaviour (handwashing) must be constantly emphasized, encouraged, repeated and taught.}

We believe that more emphasis should be placed on pre-school education in topics that include general hygiene, with an emphasis on personal hygiene and the prevention of the spread of infectious diseases.

Nudging tools used in the research can also be used in home environment and in other educational institutions

(primary and secondary schools, faculties, educational institutions, etc.) for their simplicity and affordability. observer, which may have a slight impact on the reliability of the survey. To minimize this, we have created an observation list and validated it through the observation test of participants before the observation itself. In doing so, we achieved repeatability of the research. Regardless of the limitations, we have demonstrated that simple and affordable nudging tools can improve handwashing of childcare workers and children in the kindergartens.

\section{CONCLUSION}

Based on the conducted research, we found out that the use of nudging tools in kindergartens can significantly contribute to a better implementation of hygienic behaviour of childcare workers and children. However, we emphasize that installing the nudging tools in wards alone is not sufficient or likely to work in the short term. Nudging tools should therefore be changed and designed for a limited period of time (e.g. once a month) so that they are always attractive, enjoyable and positive for children. In addition, the importance of hygiene behaviour (handwashing) must be constantly emphasized, encouraged, repeated and taught. Our research is the first of its kind to provide insight into the hygienic behaviour of childcare workers and children in two selected kindergartens in Slovenia, and the first study in which we used nudging tools to improve hygienic behaviour in Slovenian kindergartens.

In order to get a better overview of the actual state of hygiene behaviour, more kindergartens should be included in the research and the theoretical and practical knowledge of hygiene behaviour of childcare workers should be improved. We believe that more emphasis should be placed on preschool education in topics that include general hygiene, with an emphasis on personal hygiene and the prevention of the spread of infectious diseases. In order to ensure proper hygienic behaviour of childcare workers and children in the wards, each kindergarten could introduce greater control over hygiene requirements.

Such supervision could be carried out by health and hygiene regimen professional staff (e.g. once a month using an observation list). A weak point in our study is the comparison of handwashing among children of the first and second age groups (wards). Further research would have to elaborate more precisely on working methods, identifying and determining the same number of children to observe.

Nudging tools used in the research can also be used in home environment and in other educational institutions (primary and secondary schools, faculties, educational institutions, etc.) for their simplicity and affordability. There are no sufficient excuses for their non-use or absence, since the nudging tools used in the research can only have a positive response to the targeted behaviour. It is also important to emphasize, that our study was undertaken before the pandemic COVID-19 was declared. Current situation shows even higher importance in complying efficient hygiene behaviour (especially handwashing) in kindergartens to control the spread of COVID-19. 
We conclude that with nudging tools for hygienic behaviour, we can reduce the incidence of infectious diseases in kindergartens, while at the same time directing children towards the healthier and hygienically appropriate way of life by means of the appropriate hygiene behaviour.

\section{REFERENCES}

[1] Niffenegger JP. Proper handwashing promotes wellness in child care. J Pediatr Health Care. 1997; 11(1): 26-31.

[2] Au WH, Suen LKP, Kwok YL. Handwashing programme in kindergarten: a pilot study. Health Education. 2010; 110(1): 5-16.

[3] Mont O, Lehner M, Heiskanen E. Nudging. A tool for sustainable behaviour? Swedish environmental protection agency report 6643. 2014: https://www.naturvardsverket.se/Documents/publikationer6400/ 978-91-620-6643-7.pdf?pid=14232 (accessed 20. 2. 2018).

[4] Caris MG, Labuschagne HA, Dekker $M$ et al. Nudging to Improve Hand Hygiene. J Hosp Infect. 2017; (17): 352-358.

[5] White C, Kolble R, Carlson R et al. The effect of hand hygiene on illness rate among students in university residence halls. Am J Infect Control. 2003; 31(6): 364-70.

[6] Dreibelbis R, Kroeger A, Hossain $K$ et al. Behavior Change without Behavior Change Communication: Nudging Handwashing among Primary School Students in Bangladesh. Int J Environ Res Public Health. 2016; 13(1): 13-29.

[7] Gold A, Lichtenberg P. Don't call me "nudge": the ethical obligation to use effective interventions to promote public health. Am J Bioeth. 2012; 12(2): 18-20.

[8] Thaler RH, Sunstein CR. Nudge: Improving decisions about health, wealth, and happiness. New Haven, CT. Yale University Press. 2008.

[9] Ovca A. Izpis kriterijev in norm za vrtec. In: Bauer M, Bičič E, Ferfila $\mathrm{N}$ et al., eds. Higiena objektov in procesov. Univerzitetni učbenik za študente sanitarnega inženirstva, 2. izdaja. Univerza v Ljubljani, Zdravstvena fakulteta. Ljubljana. 2017; 269-278.

[10] Likar K, Bauer M.Izbrana poglavja iz higiene. Univerza v Ljubljani, Visoka šola za zdravstvo. Ljubljana. 2006.

[11] Video Oskar. Clean hands for healthy children (Čiste roke za zdrave otroke). 2013: http://www.video-oskar.com/ciste-roke-za-zdrave-otroke/ (accessed 20. 4. 2018).

[12] WHO - World Health Organization. Hand hygiene technical reference manual: to be used by health-care workers, trainers and observers of hand hygiene practices. 2009: https://apps.who.int/iris/bitstream/ handle/10665/44196/9789241598606 eng.pdf;jsessionid=E6A46AE 25337021051B0EB15E9C4888F?sequence=1 (accessed 25. 2. 2018).

[13] Helder OK, Weggelaar AM, Waarsenburg DCJ et al. Computer screensaver hand hygiene information curbs a negative trend in hand hygiene behavior. Am J Infect Control. 2012; 40(10): 951-954.

[14] Mlakar T, Mihelič-Zajec A, Jevšnik M. Use of a nudge tool for improving hand hygiene in a nursing team in home for elderly people - case study. Int J Sanitary Engineering Research. 2017; 11(1/2017): 33-46.

[15] Zarisha D, Darmawan B, Raksanagara AS et al. Knowledge of Personal Hygiene among Food Handlers in Canteen at Faculty of Medicine. Universitas Padjadjaran, October to November 2012. Althea Medical Journal. 2015; 2(2): 245-249.

[16] Kubde SR, Pattankar J, Kokiwar PR. Knowledge and food hygiene among food handlers in food establishments. Int J Community Med Public Health. 2016; 3(1): 251-256.

[17] Zabukošek M, Jevšnik M, Maletič M. Analysis of dimensionality of food safety culture: An empirical examination of a Slovenian food processing 
company. Int J Sanitary Engineering Research. 2016; 10(1/2016): 2034.

[18] Ambrožič $M$, Kukec $A$, Jevšnik $M$ et al. Food safety expertise among professional food handlers and consumers related to foodborne viruses: Case Slovenia. Int J Sanitary Engineering Research. 2016; 10(1): 4-19.

[19] Curtis V, Kanki B, Cousens $S$ et al. Evidence of behaviour change following a hygiene promotion programme in Burkina Faso. Bull World Health Org Suppl. 2001; 79(6): 518-27.

[20] Centers for Disease Control and Prevention. Handwashing: Clean Hands Save Lives. When and How to Wash Your Hands. 2016: https://www.cdc. gov/handwashing/when-how-handwashing.html (accessed 10. 12. 2019). 